\title{
PENELITIAN CAMPURAN LATASTON $A C$ - WC DENGAN MENGGUNAKAN AGREGAT HALUS LIMBAH BATUBARA
}

\author{
Doni Prayoga*1, Sigit Winarto², Yosep Cahyo ${ }^{3}$. \\ ${ }^{1,2,3}$ Fakultas Teknik, Universitas Kadiri. \\ email : *1 donyprayoga@gmail.com. ${ }^{2}$ sigit.winarto@unik-kediri.ac.id, \\ 3 yosef.cs@unik-kediri.ac.id.
}

\begin{abstract}
This study aims to determine the optimum asphalt content produced in a mixture of asphalt concrete with a fine aggregate of coal waste using the Marshall Method. This study uses AC 60/70 asphalt oil, with variations in asphalt levels, namely 6\%, 6.5\%, 7\%, 7.5\%, and 8\%. The sample used consisted of 3 variants of sample specimens. Stages of research activities include coarse coral aggregate suspended by sieve no. $8(2,36 \mathrm{~mm})$, fine aggregate with coal waste through filter no. $8(2,36 \mathrm{~mm})$, and the cement filler pass through filter no. $200(0.075 \mathrm{~mm})$. The test results of this research are the optimum asphalt content of $7.5 \%$, $8 \%$ with a stability of 2717, 3447, Flow $3.4 \mathrm{~mm}, 3.8 \mathrm{~mm}$, VIM 3.4\%, 4.91\%, 16.05\%, $17,39 \%$, VFB $78.2 \%, 70.9 \%, M Q$ value, $846 \mathrm{~kg} / \mathrm{mm}, 835 \mathrm{~kg} / \mathrm{mm}$. The test results show that the samples tested have met the 2010 Binamarga requirements with an asphalt content efficiency value of $7.8 \%$. Excessive use results in blending, and if too little will result in a crack.
\end{abstract}

Keywords : Coal waste, Concrete Asphalt, Marshall Method, Asphalt Content

\begin{abstract}
Abstrak
Penelitian ini bertujuan untuk mengetahui kadar aspal optimum yang dihasilkan pada campuran aspal beton dengan agregat halus limbah Batubara dengan Metode Marshall. Penelitian ini menggunakan aspal minyak AC 60/70, dengan variasi kadar aspal yaitu: 6\%, 6,5\%, 7\%, 7,5\%, dan 8\%. Sampel yang dipakai terdiri dari 3 varian sampel benda uji. Tahapan kegiatan penelitian meliputi agregat kasar batu koral tertahan saringan no. $8(2,36 \mathrm{~mm})$, agregat halus dengan limbah batubara lolos saringan no. $8(2,36 \mathrm{~mm})$, dan filler semen lolos saringan no. $200(0,075 \mathrm{~mm})$. Hasil uji dari penelitian ini yaitu kadar Aspal Optimum 7,5 \%, 8\% dengan stabilitas 2717, 3447, Flow 3,4 mm, 3,8 mm, VIM 3,4 \%, 4,91 \%,16,05\%, $17,39 \%$, VFB 78,2 \%, 70,9\%, nilai MQ,846 kg/mm, $835 \mathrm{~kg} / \mathrm{mm}$. Hasil pengujian menunjukkan bahwa sampel yang diuji telah memenuhi syarat binamarga 2010 dengan nilai efisiensi kadar aspal 7,8 \%. Penggunaan yang berlebihan mengakibatkan terjadinya blending dan jika terlalu sedikit akan mengakibatkan terjadinya crack.
\end{abstract}

Kata Kunci : Limbah Batu Bara, Aspal Beton, Metode Marshall, Kadar Aspal 


\section{PENDAHULUAN}

Aspal beton sebagai bahan untuk konstruksi jalan sudah lama dikenal dan digunakan secara luas dalam pembuatan jalan [1]. Penggunaannya pun di Indonesia dari tahun ketahun makin meningkat [2], terutama untuk mendukung pembangnan konstruksi yang pesat khususnya di kota besar [3]. Hal ini penyebabnya tidak lain adalah karena aspal beton mempunyai kelebihan dibanding bahan lainnya. Disamping harga yang relatif lebih murah dibanding beton,Aspal beton dapat mendukung beban berat kendaraan yang tinggi dan aspal beton dapat dibuat dari bahan-bahan lokal yang tersedianya serta mempunyai ketahanan yang baik terhadap cuaca. Jenis perkerasan ini merupakan campuran merata antara agregat dan aspal sebagai bahan pengikat pada suhu tertentu [4]. Aspal didefinisikan sebagai material berwarna hitam atau coklat tua, pada temperatur ruang berbentuk padat sampai agak padat [5]. Jika dipanaskan sampai suatu temperatur tertentu, aspal dapat menjadi lunak/cair sehingga dapat membungkus partikel agregat pada waktu pembuatan aspal beton [6]. Aspal beton (laston) yang secara umum digunakan secara luas dipelbagai negara, mempunyai kepadatan yang tinggi, nilai struktural tinggi dan kadar aspal yang rendah. Hal ini biasanya mengarah menjadi suatu bahan yang relatif kaku, sehingga konsekuensi ketahanan rendah dan keawetan yang terjadi rendah pula [7].

Agregat halus adalah agregat hasil pemecah batu yang mempunyai sifat lolos saringan No.8 (2,36 mm), sesuai SNI 03-6819-2002 [8]. Fungsinya untuk menyediakan stabilitas dan mengurangi deformasi permanen dari perkerasan melalui keadaan saling mengunci dan gesekan antar butiran. Agregat halus menggunakan pasir sungai brantas, saringan yang digunakan adalah tertahan saringan no. 16, 30, 50, 100, dan 200[9]. Sumber material apa pun harus mencakup pengalihan pasir atau batu pecah dan material yang melewati saringan $8(2,36 \mathrm{~mm})$ sesuai SNI 03-6819-2002. Pecahan agregat halus pasir harus dipisahkan dari agregat kasar [10].

Penelitian ini memanfaatkan limbah batubara dari bahan bakar pabrik produksi yang terletak di daerah penulis. Limbah batubara digunakan sebagai campuran aspal beton AC-WC sebagai agregasi halus. Limbah batubara umumnya di hasilkan dari pembakaran batubara pada pembangkit tenaga listrik yaitu bottom boilers [11]. Ada dua jenis abu batubara, yaitu abu terbang dan abu dasar. Abu dasar hanya 10-20\% dari total abu batubara dan biasanya dikumpulkan di lantai atau di sekitar tungku karena terlalu berat untuk dibawa oleh gas buang [12][13]. Abu aslinya biasanya berwarna lebih gelap dan ukuran butiran bervariasi dari pasir ke kerikil. Komposisi kimiawi abu dasar mendominasi pada tingkat $\mathrm{SiO} 2$ dan $\mathrm{AI} 2 \mathrm{O} 3$ dan $\mathrm{CaO}$. Dibandingkan dengan abu layang, abu dasar biasanya memiliki kadar karbon residual yang lebih tinggi [14][15][16]. Tujuan dari penelitian ini adalah untuk mengetahui hasil uji dari Aspal Beton dengan campuran limbah batu bara aspal dengan metode Marshall, mengetahui Kadar Aspal Optimum yang dihasilkan pada Aspal Beton dengan campuran limbah batubara, 
mengetahui hasil uji dari campuran Aspal Beton AC-WC dengan menggunakan limbah batubara memenuhi spesifikasi dari Bina Marga [17].

\section{METODE PENELITIAN}

\subsection{Tahap Pengujian.}

Penelitian yang akan dilakukan memiliki beberapa tahap pengujian, adapun dalam pengujian tersebut meliputi :

A. Persiapan.

Pada tahap ini menyiapkan bahan yang akan digunakan dan mempersiapan bahan seperti aspal, agregat kasar batu pecah, agregat halus limbah batubara, filler semen. Hasil pengujian bahan mengacu pada standard SNI diantaranya penetrasi aspal $25^{\circ}(\mathrm{mm})$ mengacu pada SNI 06-2456-1991. Titik Lembek aspal $\left({ }^{\circ} \mathrm{C}\right)$ mengacu pada SNI 06-2434-1991. Daktilitas pada aspal $25^{\circ}(\mathrm{cm})$ mengacu SNI 06-2432-1991. Kehilangan berat pada aspal mengacu pada SNI 06-2440-1991. Berat jenis aspal mengacu pada SNI 06-2441-1991. Metode spesifikasi pengujian karakteristik agregat kasar dengan jenis pengujian standard SNI diantaranya berat jenis mengacu standard SNI 03-1969-1990. Penyerapan air mengacu pada SNI 03-19691990. Analisa saringan mengacu pada standard uji SNI 03-1968-1990. Keausan agregat dengan mesin los angeles pengacu pada SNI 2417-2008. Indeks kepipihan mengacu pada RSNI T-01-2005 [18]. Metode spesifikasi pengujian karakteristik agregat halus dan filler dengan jenis pengujian standard SNI diantaramya berat jenis yang mengacu pada standard uji SNI 03-1970-1990. Analisa saringan mengacu pada standard SNI 03-1968-1990. Penyerapan air mengacu pada standard SNI 03-1970-1990. Sand equivalent pengacu pada standard SNI 03-4428-1997 [19].

B. Perencanaan Campuran.

Peraturan tentang komposisi campuran AC-WC dari 65\% agregat kasar, 29\% agregat halus limbah batubara dan semen $6 \%$ (filler) [20]. Untuk memperoleh campuran yang ideal dan memberikan kinerja yang baik dan optimal, sebelum membuat campuran, rencana pencampuran untuk menentukan komposisi setiap komponen untuk mendapatkan campuran aspal yang memenuhi spesifikasi [21] pada Pengambilan gradasi agregat campuran AC-WC dengan mengambilan batas bawah dan batas tengah dari setiap berat lolos saringan dengan acuan spesifikasi Bina Marga 2010 , Atau yang telah tertera pada Tabel 1. 
Tabel 1. Gradasi Agregat.

\begin{tabular}{|c|c|c|c|}
\hline \multirow{3}{*}{$\begin{array}{l}\text { Ukuran Ayakan } \\
\text { (mm) }\end{array}$} & \multicolumn{3}{|c|}{ \% Berat Yang Lolos Terhadap Total Agregat Dalam Campuran } \\
\hline & \multicolumn{3}{|c|}{ Laston $A C$} \\
\hline & $A C-W C$ & $A C-B C$ & AC-Base \\
\hline 37,5 & - & - & 100 \\
\hline 25 & - & 100 & $90-100$ \\
\hline 19 & 100 & $90-100$ & $76-90$ \\
\hline 12,5 & $90-100$ & $75-90$ & $60-78$ \\
\hline 9,5 & $77-90$ & $66-82$ & $52-71$ \\
\hline 4,75 & $53-69$ & $46-64$ & $35-54$ \\
\hline 2,36 & $33-534$ & $30-494$ & $23-41$ \\
\hline 1,180 & $21-404$ & $18-384$ & $13-30$ \\
\hline 0,69 & $14-304$ & $12-284$ & $10-22$ \\
\hline 0,35 & $9-224$ & $7-204$ & $6-15$ \\
\hline 0,157 & $6-154$ & $5-134$ & $4-10$ \\
\hline 0,0750 & $4-94$ & $4-84$ & $3-7$ \\
\hline
\end{tabular}

Sumber : Gradasi Agregat Lolos Terhadap Total Campuran

Langkah - langkah dalam perencanaan campuran dapat dilakukan pengujian sebagai berikut :

1. Pembuatan dan pengujian benda uji

Benda uji dan kadar aspal awal.

Menyiapkan kadar aspal pada 23 sampel kadar aspal berada diatas nilai $\mathrm{Pb}$. Untuk 23 sampel kadar aspal berada dibawah nilai $\mathrm{Pb}$. Kadar aspal $(\mathrm{Pb})-1,0 \%$, Kadar aspal $(\mathrm{Pb})-0,5 \%$, Kadar aspal $(\mathrm{Pb})$, Kadar aspal $(\mathrm{Pb})+0,5 \%$, Kadar aspal $(\mathrm{Pb})+1,0 \%$. 
2. Pengujian dengan Alat Marshall.

Benda uji direndam terlebih dahulu dalam water bath dengan suhu $60^{\circ} \mathrm{C}$ selama 30 menit.

Pembersihan kepala Marshall dan diberi pelumas. Meletakkan benda uji pada alat uji Marshall yang sudah diberi flow meter dan arloji pembebanan. Pembebanan dilakukan hingga maksimum. Langkah langkah diatas dapat dinarasikan kedalam alur penelitian

Gambar 1. dibawah ini :

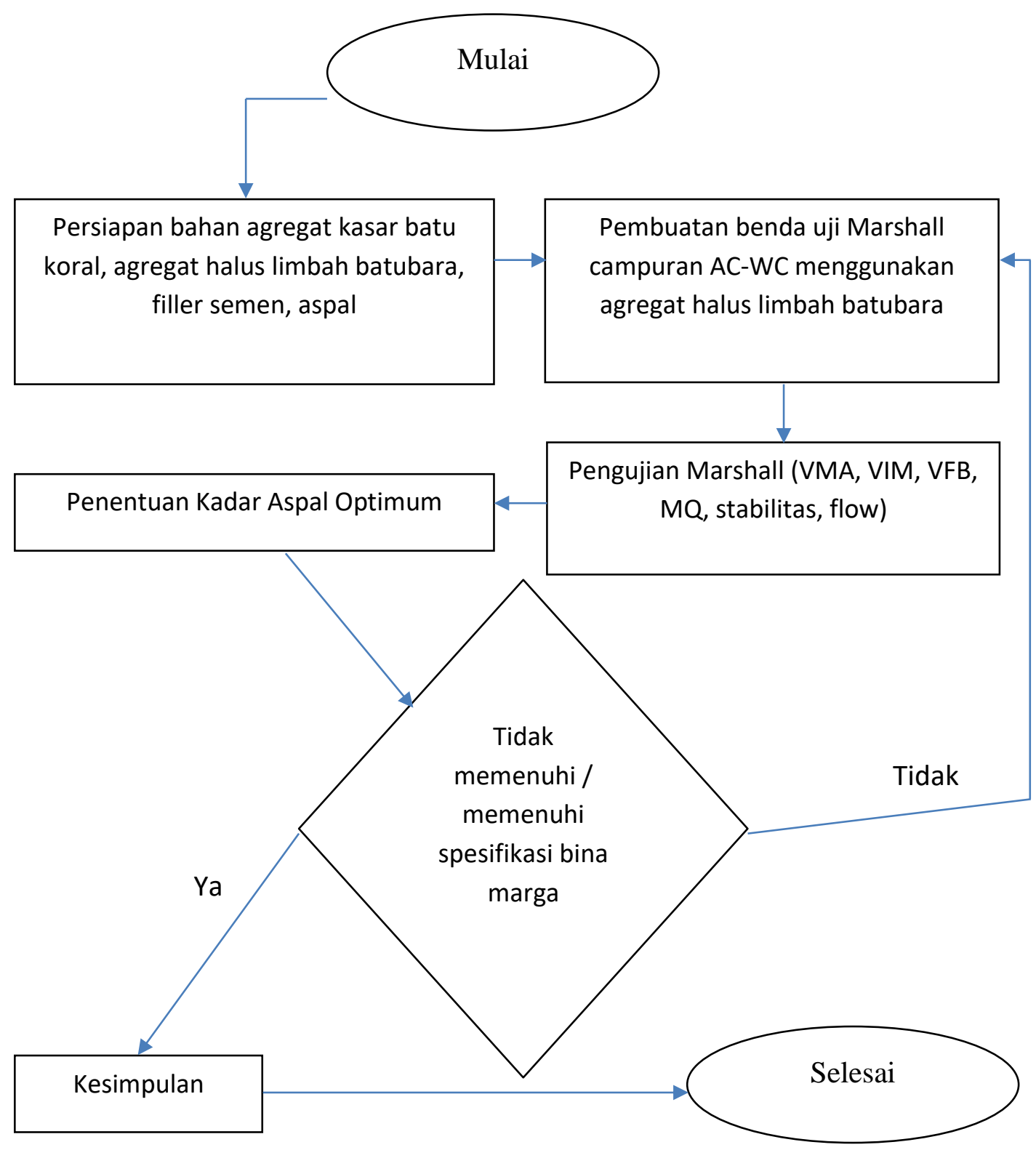

Sumber : Alur Penelitian.

Gambar 1. Alur Penelitian. 


\section{HASIL DAN PEMBAHASAN}

\subsection{Hasil Uji AC - WC.}

Hasil pengujian karakteristik campuran $A C$-WC dengan Metode Marshall dapat dilihat dari grafik pada Gambar 2. dengan VIM, VMA, MQ, Stabilitas dan flow.

\subsection{Hubungan kadar Aspal Minyak Dengan VIM ( Voids In Mix).}

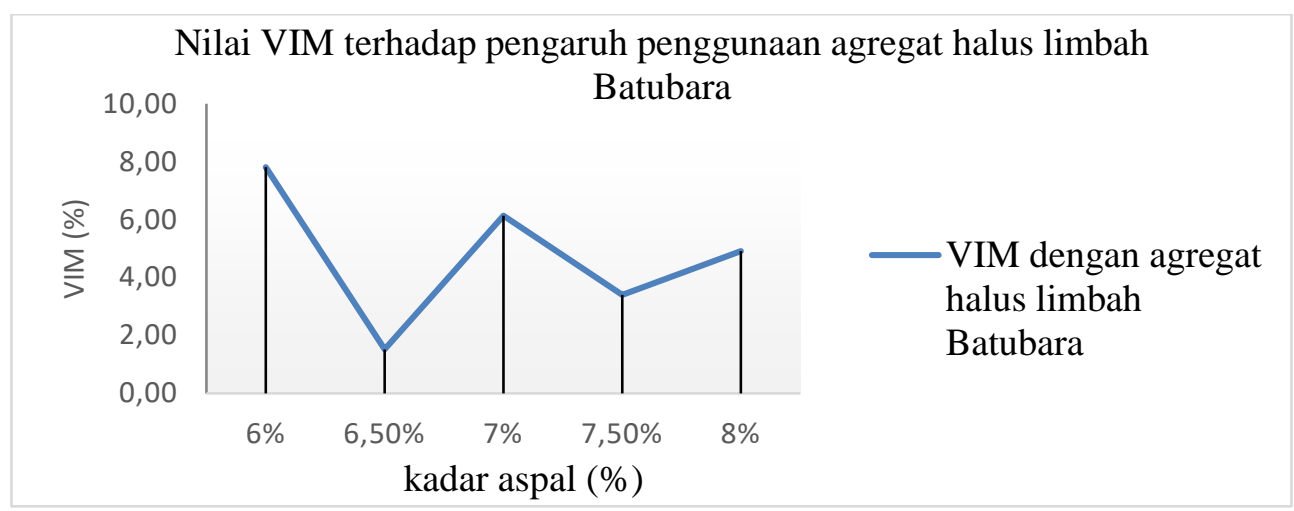

Sumber : Grafik Nilai VIM.

Gambar 2. Hubungan Kadar Aspal Minyak Dengan Nilai VIM.

Berdasarkan gambar diatas menunjukkan hasil nilai rata-rata VIM kadar aspal 6\% senilai $7,91 \%$, pada $6,5 \%$ senilai $1,91 \%$, pada $7 \%$ senilai $6,27 \%$, pada $7,5 \%$ senilai $3,44 \%$ dan pada $8 \%$ adalah senilai $4,92 \%$.

\subsection{Hubungan Kadar Aspal Minyak Dengna VMA (Voids Mineral Aggregate).}

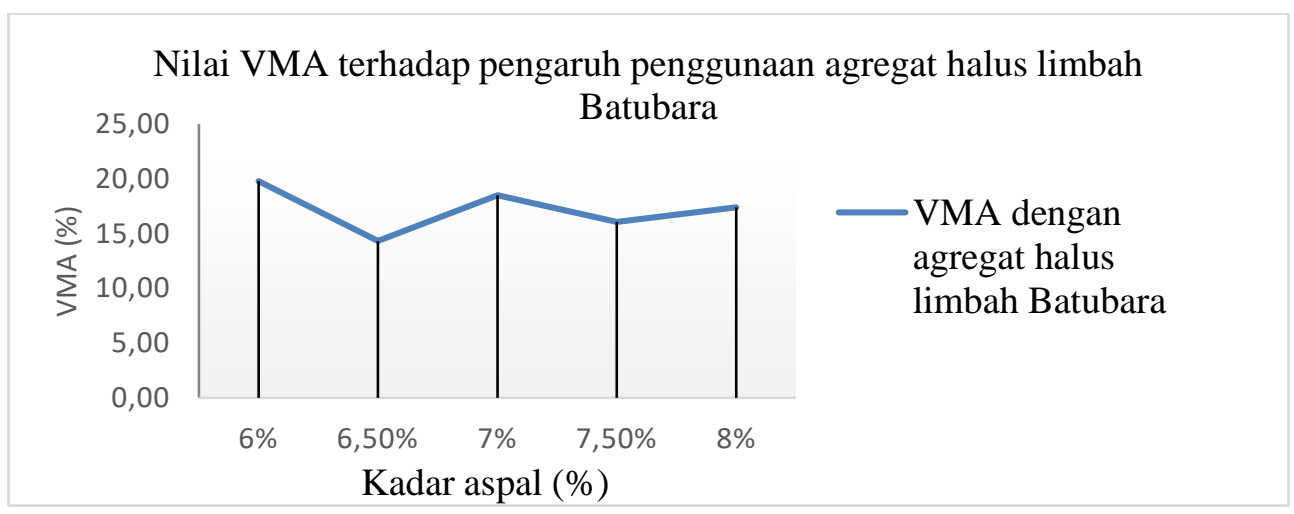

Sumber : Grafik Nilai VMA.

Gambar 3. Hubungan Antara Kadar Aspal Minyak Terhadap Nilai VMA.

Berdasarkan gambar diatas menunjukkan nilai rata-rata VMA kadar aspal $6 \%$ senilai $19,87 \%$, pada $6,5 \%$ senilai $14,26 \%$, pada $7 \%$ senilai $18,43 \%$, pada $7,5 \%$ senilai $15,98 \%$, pada $8 \%$ senilai $17,26 \%$. 


\subsection{Hubungan Kadar Aspal Minyak Dengan VFB (Voids Filled Bitumen).}

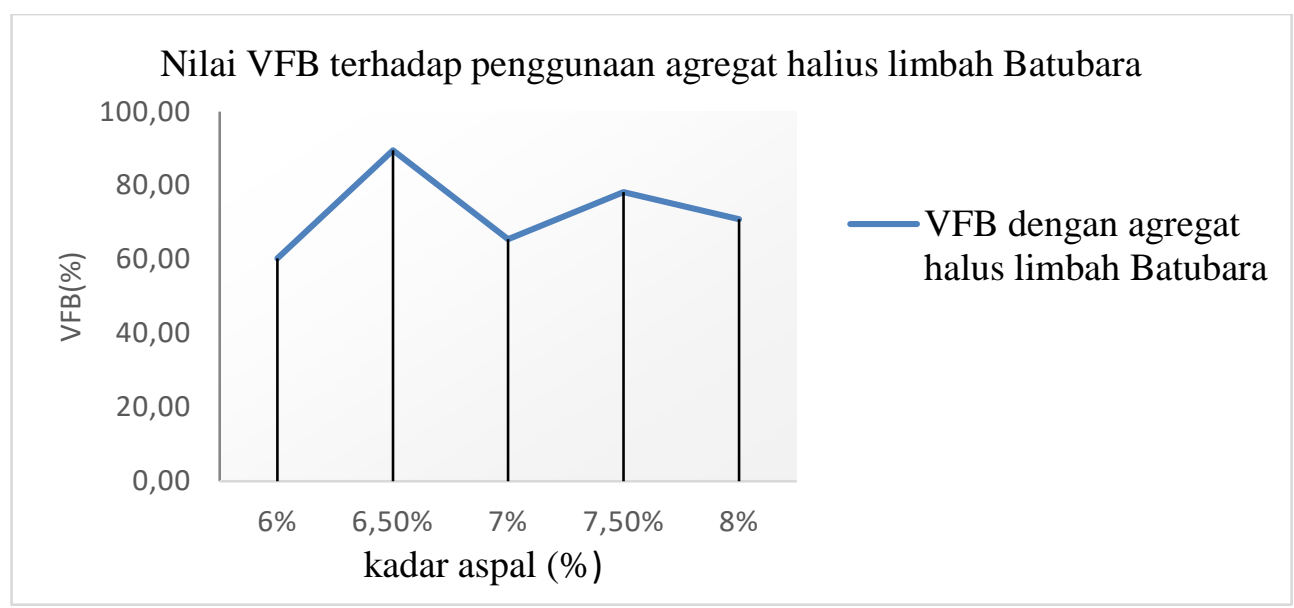

Sumber : Grafik Nilai VFB.

Gambar 4. Hubungan Kandungan Kadar Aspal Minyak Dengan Nilai VFB.

Berdasarkan gambar diatas menunjukan nilai rata-rata VFB kadar aspal 6\% senilai $60,19 \%$, pada $6,5 \%$ senilai $89,62 \%$, pada $7 \%$ senilai $65,97 \%$, pada $7,5 \%$ senilai $78,48 \%$ dan pada $8 \%$ senilai $71,5 \%$.

\subsection{Hubungan Kadar Aspal Minyak Dengan Stabilitas.}

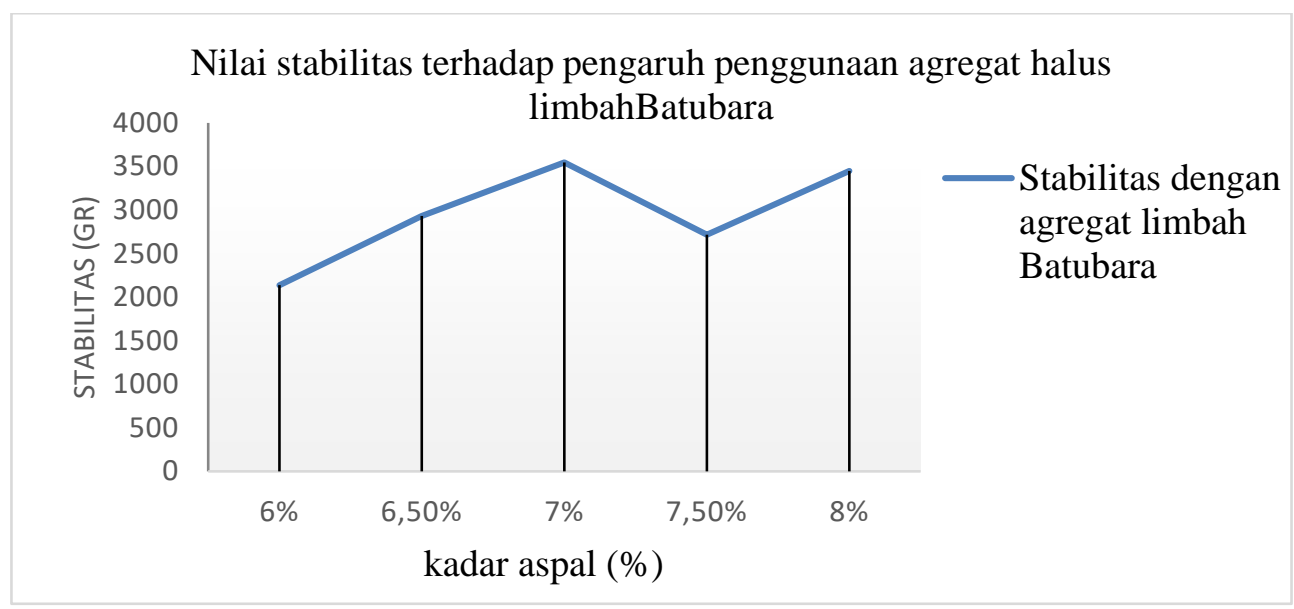

Sumber : Grafik Nilai Stabilitas.

Gambar 5. Gambar Hubungan Antara Kadar Aspal Dengan Nilai Stabilitas.

Berdasarkan gambar diatas menunjukkan hasil nilai rata-rata Stabilitas dengan kadar aspal $6 \%$ senilai $2182 \mathrm{~kg} / \mathrm{mm}$, pada $6,5 \%$ senilai $2913 \mathrm{~kg} / \mathrm{mm}$, pada $7 \%$ senilai $3538 \mathrm{~kg} / \mathrm{mm}$, pada $7,5 \%$ senilai $2703 \mathrm{~kg} / \mathrm{mm}$ dan pada $8 \%$ senilai $3485 \mathrm{~kg} / \mathrm{mm}$. 


\subsection{Hubungan Kadar Aspal Dengan Flow.}

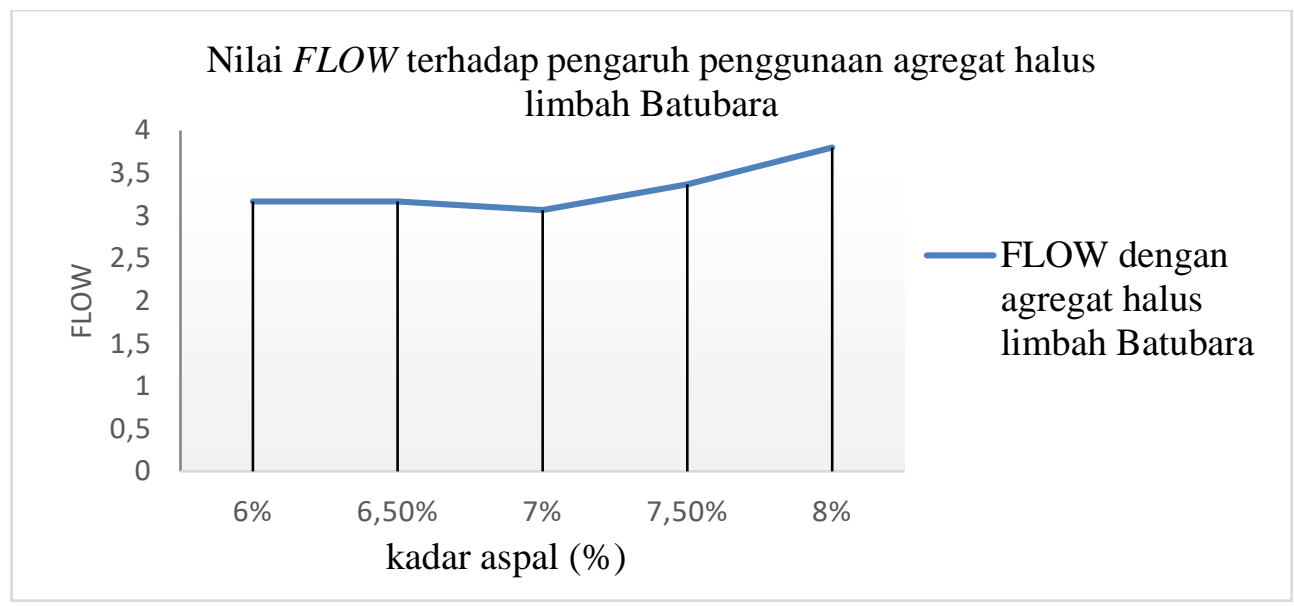

Sumber : Grafik Nilai Flow.

Gambar 6. Hubungan Antar Kadar Aspal Dengan Nilai Flow.

Berdasarkan Gambar Diatas Menunjukkan Hasil Nilai Rata-Rata Flow Dengan Kadar Aspal 6\% Senilai 3, Pada 6,5 \% Senilai 3, Pada 7 \% Senilai 3, Pada 7,5 \% Senilai Dan Pada $8 \%$ Senilai 4.

3.6 Hubungan Kadar Aspal Dengan MQ (Marshall Quetiont).

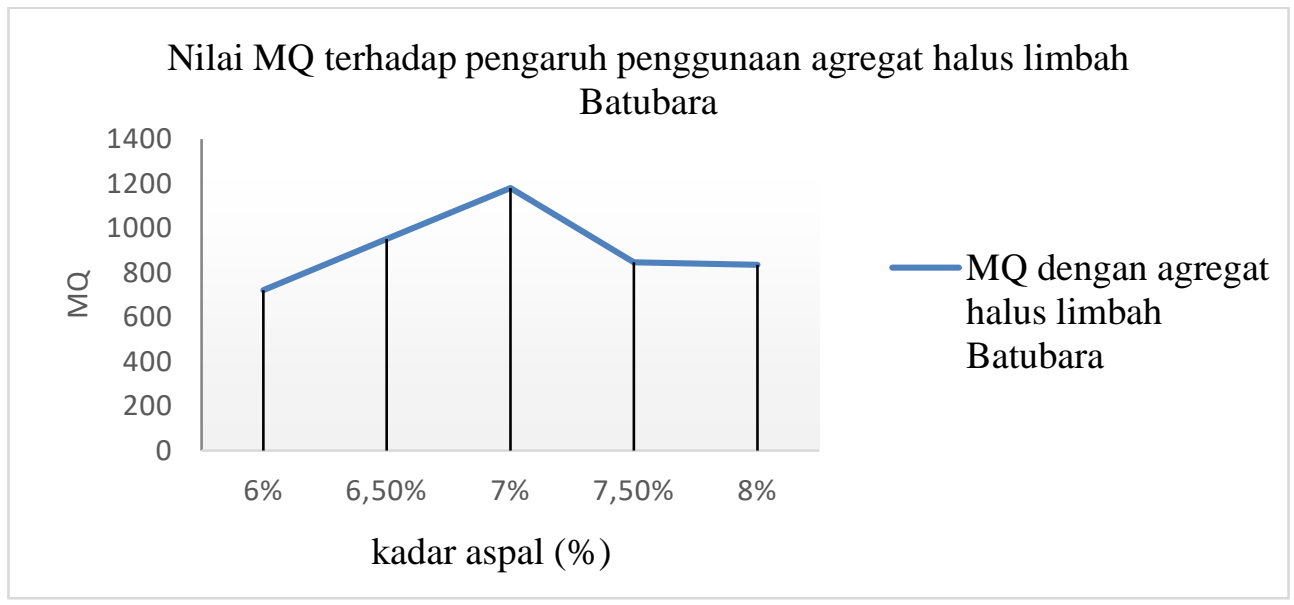

Sumber : Grafik Nilai $M Q$.

Gambar 7. Hubungan kandungan kadar aspal minyak dengan Marshall Quetiont.

Dari Gambar 7 terlihat hasil nilai rata-rata MQ dengan kadar aspal 6\% senilai 727, pada $6,5 \%$ senilai 971 , pada $7 \%$ senilai 1179 pada $7,5 \%$ senilai 845 dan pada $8 \%$ senilai 871. 


\section{KESIMPULAN}

Hasil uji campuran aspal beton menggunakan agregat halus limbah batubara menggunakan Metode Marshall di laboratorium Universitas Kadiri adalah sebagai berikut :

1. Kandungan kadar aspal minyak dan seluruh parameter marshall dan volumetrik menggunakan agregat halus limbah batubara berada pada kadar 7,5\% dan $8 \%$ dari Nilai VIM, VMA, VFB, Stabilitas dan $M Q$.

2. Berarti penggunaan yang memenuhi syarat binamarga 2010 revisi 3 dapat nilai efisiensi dengan kadar aspal 7,8 \% penggunaan terbaik jika lebih dari itu akan terjadinya blending dan jika berkurang akan terjadinya crack.

\section{SARAN}

Dari hasil penelitian yang didapat, maka saran yang bisa disampaikan yaitu untuk selalu diharapkan pada penelitian ini kita dapat memakai atau menerapkan hasil uji ini di lapangan dengan menggunakan aspal campuran limbah batubara, dan adanya ini kita dapat memanfaatkan limbah batubara sebagai campuran aspal. Penggunaan yang berlebihan mengakibatkan terjadinya blending dan jika terlalu sedikit akan mengakibatkan terjadinya crack.

\section{UCAPAN TERIMAKASIH}

Dalam melakukan penyusunan artikel ilmiah ini, mungkin tidak akan terlaksana tanpa bantuan, dorongan, bimbingan dan petunjuk dari berbagai pihak, terutama kedua Orang tua penulis. Selain itu, saya juga ingin menyampaikan rasa terimakasih kepada Dosen Pembimbing yang telah bersedia meluangkan waktu untuk memberikan bimbingan, pengarahan, dan saran. Akhir kata, penulis berharap agar artikel ilmiah ini dapat bermanfaat bagi pembaca. 


\section{DAFTAR PUSTAKA}

[1] Supriadi, Y. C. S. P, A. Ridwan, and A. I. Candra, "PENELITIAN PENAMBAHAN BAHAN BATU PADAS PADA CAMPURAN ASPAL BETON,” Jurmateks, vol. 2, no. 1, pp. 154-163, 2019.

[2] M. R. E. Manoppo, D. Jurusan, T. Sipil, F. Teknik, U. Sam, and R. Manado, "Pemanfaatan Tras Sebagai Filler Dalam Campuran Aspal Panas Hrs -Wc," vol. 1, no. 2, pp. 102-107, 2011.

[3] S. Susanto, "PERBANDINGAN FUNGSI KEANGGOTAAN TIPE SEGITIGA DAN TIPE GBELLTERHADAPANALISIS RISIKO,” vol. 3, no. 2, pp. 57-67, 2019.

[4] M. I. Baiquni, A. K. Hidayat, P. Studi, T. Sipil, F. Teknik, and U. Siliwangi, "Kata Kunci : Aspal Beton , Filler, Kadar Aspal Optimum , Marshall , Mortar .,” vol. 1, no. 1, pp. 16-23, 1995.

[5] B. Jimbaran-bali, "MENENTUKAN KOMPOSISI OPTIMAL DARI FAKTORFAKTOR YANG MEMENGARUHI KETAHANAN ASPAL," vol. 2, no. 1, pp. 37-41, 2013.

[6] S. Arifin, M. Kasan, and N. Pradani, "Pengaruh nilai abrasi agregat terhadap karakteristik beton aspal," Smartek, vol. 5, no. 1, pp. 1-11, 2007.

[7] Suhardi, P. Pratomo, and H. Ali, "Study of Marshall Characteristics due to Asphalt Mixture with the Addition of Plastic Bottle Waste," J. Civ. Eng. Des., vol. 4, no. 2, pp. 284-293, 2016.

[8] H. Ali, "pada Aspal Concrete - Wearing Course ( ACWC ) Gradasi Halus," vol. 3, no. 2, pp. 171-184, 2015.

[9] H. Wahyudiono, B. Winarno, K. C. Budi, T. Sipil, F. Teknik, and U. Kadiri, “MODIFIKASI LASTON AC-WC MENGGUNAKAN LIMBAH BONGKARAN," vol. 12, no. 1, pp. 33-40, 2020.

[10] A. Gunarto and A. I. Candra, "Menggunakan Filler Bunga Pinus," vol. 3, no. 1, pp. 45$53,2019$.

[11] M. Aminuddin, A. I. Candra, and Y. C. S, "JOB MIX LASTON (AC-BC) MENGGUNAKAN BUBUK GYPSUM DAN ABU BATA MERAH,” Jurmateks, vol. 1, no. 2, pp. 325-335, 2018.

[12] D. A. N. R. Blend, "MEMAKAI AGREGAT KARANG GUNUNG DARI SABANG DENGAN BAHAN PENGIKAT ASPAL PEN 60 / 70,” vol. 18, no. 2, pp. 127-134, 
2018.

[13] A. Gunarto and A. I. Candra, "Penelitian Campuran Aspal Beton Dengan Menggunakan Filler Bunga Pinus,” UKaRsT, vol. 3, no. 1, p. 37, 2019, doi: 10.30737/ukarst.v3i1.351.

[14] S. A. B. Samodera, Y. C. S. P, A. Ridwan, and A. Iwan, "PENELITIAN PENAMBAHAN SERBUK BATA MERAH DAN PASIR BRANTAS PADA ASPAL BETON," Jurmateks, vol. 2, no. 2, pp. 256-266, 2019.

[15] A. I. Candra, S. W. Mudjanarko, and P. Vitasmoro, "Analysis of the Ratio of Coarse Aggregate to Porous Asphalt Mixture ANALYSIS of THE RATIO of COARSE AGGREGATE to POROUS ASPHALt MIXTURE,” J. Phys. Conf. Ser., pp. 1-6, 2020, doi: 10.1088/1742-6596/1569/4/042029.

[16] F. A. Yusuf, A. Ridwan, and Y. C. S. P, "PENELITIAN PENAMBAHAN BAHAN SERBUK DOLOMITE DAN PASIR BRANTAS PADA CAMPURAN ASPAL BETON," Jurmateks, vol. 2, no. 2, pp. 205-214, 2019.

[17] I. M. Ardianti, "Analisis Kualitas Campuran Aspal Panas Menggunakan Berbagai Aspal Modifikasi,”vol. 1, no. 4, pp. 1-93, 2018.

[18] C. Khairani, S. M. Saleh, and S. Sugiarto, "Uji Marshall Pada Campuran Asphalt Concrete Binder Course (Ac-Bc) Dengan Tambahan Parutan Ban Bekas,” J. Tek. Sipil, vol. 1, no. 3, pp. 559-570, 2018, doi: 10.24815/jts.v1i3.9995.

[19] D. P. Umum, Spesifikasi Umum Binamarga 2010 Revisi 3, vol. umum. 2010.

[20] S. Pengajar et al., "MIX DESIGN ASPHALT CONCRETE WEARING COURSE ( ACWC ) DENGAN MENGGUNAKAN FLY ASH BATU BARA,” vol. 2, no. 1, pp. 133144, 2014.

[21] I. Gusti Raka Puranto and I. Nyoman Sapta Nugraha, "Studi Karakteristik Campuran Aspal Beton Lapis Aus (AC-WC) Menggunakan Aspal Penetrasi 60/70 dengan Penambahan Lateks," vol. 22, no. 2, pp. 77-86, 2016. 